\title{
Sources of dietary lipids in the coral reef blenny Salarias patzneri
}

\author{
Shaun K. Wilson ${ }^{1, *}$, Kathryn Burns ${ }^{2}$, Susan Codi $^{2}$ \\ ${ }^{1}$ Department of Marine Biology and Aquaculture, James Cook University, Townsville, Queensland 4811, Australia \\ ${ }^{2}$ Australian Institute of Marine Science, PO Box 3, Townsville, Queensland 4810, Australia
}

\begin{abstract}
The composition of essential fatty acids and biomarkers in the tissues of the blenny Salarias patzneri were compared to those in detritus and filamentous algae collected from $S$. patzneri territories in order to assess the relative contribution of these 2 resources to the diet. The ratio of

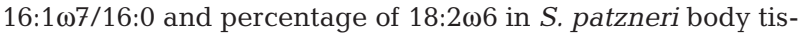
sue and detritus was found to be significantly different to filamentous algae samples, suggesting that detritus was the major source of dietary lipids assimilated by $S$. patzneri. High levels of 16:1 $\omega 7$ in $S$. patzneri tissue and detritus relative to filamentous algae suggest that diatoms are an important component of detrital aggregates and $S$. patzneri diet. These results demonstrate that coral reef fishes assimilate detrital aggregates and confirm that detritus is a valuable dietary resource on coral reefs.
\end{abstract}

KEY WORDS: Coral reef fish - Detritus - Filamentous algae · Blenniidae $\cdot$ Tropho-dynamics

Resale or republication not permitted without written consent of the publisher

It is believed that on coral reefs the consumption of epilithic algae by herbivorous fishes and invertebrates is the primary mode of energy transfer (Hatcher 1983). However, many of the coral reef fish that feed on the epilithic algal community also ingest detritus and associated micro-organisms (Choat 1991) and it is possible that these detrital aggregates are an important component of fish diets. Consequently, epilithic algal communities represent a complex of potential dietary sources that may be more accurately described as the epilithic algal matrix (EAM) (Wilson \& Bellwood 1997). Detritus collected from the territories of fishes that feed on the EAM contains a large proportion of the organic matter and nitrogen available to fish (Wilson \& Bellwood 1997, Wilson 2000); however, it is yet to be established if detritus ingested by coral reef fish is assimilated. Consequently, the value of dietary detritus to fish and its role in coral reef trophodynamics remains equivocal.

In fish, lipids rather than carbohydrates are the major source of energy reserves (Cowey \& Sargent 1977).

*E-mail: shaun.wilson@jcu.edu.au
Lipids can be obtained directly from the diet or synthesised de novo by the fish, although some fatty acids are considered essential and must be obtained through the fishes diet (Bell et al. 1986). By comparing the fatty acid content of fish with available dietary items, it is possible to get an indication of which fatty acids and dietary items are being assimilated. Experiments with specific fatty acid biomarkers and ratios of fatty acids have previously been used to demonstrate the movement of energy from microalgae (Fraser et al. 1989, Klungsoyr et al. 1989), bacteria (Ederington et al. 1995, Goedkoop et al. 1998) and copepods (Gatten et al. 1983) through the food chain. These biomarkers and ratios have also identified components of fish diets (Fraser et al. 1989, St John \& Lund 1996, Saito et al. 1999) and therefore comparisons of fatty acid biomarkers in detritus and filamentous algae with fish tissues may help identify which of these EAM components fishes assimilate.

The salariin blennies represent a substantial proportion of coral reef fish communities that feed on the EAM (Townsend \& Tibbetts 2000, Wilson in press) and may play an important role in reef trophodynamics. Blennies predominantly ingest detrital aggregates with some filamentous algae, which represent the 2 major sources of organic matter available to these fishes (Wilson 2000). By comparing the essential fatty acids and dietary biomarker content of fish tissues with detritus and filamentous algae collected from the territories of a representative blenny species, Salarias patzneri, this study will qualitatively assess the extent to which detritus or filamentous algae satisfy the lipid requirements of this fish. This will provide a new perspective on the potential assimilation of detritus and filamentous algae by blennies, and indicate if ingested detritus is used as a dietary resource by coral reef fishes.

Methods. Six Salarias patzneri were collected from the Lizard Island lagoon $\left(14^{\circ} 42^{\prime} \mathrm{S}, 145^{\circ} 30^{\prime} \mathrm{E}\right)$ during August 1998 (Austral winter) and another 6 during February 1999 (Austral summer). All S. patzneri were 
mature males, with a minimum total length of $35 \mathrm{~mm}$. They were collected using the anaesthetic clove oil and sexed by examination of the genital papillae. A sample of the detritus and algae from within each $S$. patzneri territory was collected 10 to 15 min before each fish was caught. Detritus and algae samples were collected using an underwater sampler (Purcell 1996) and followed the technique of Wilson (2000). This produced detritus samples that were predominantly composed of detrital aggregates, which were defined as a combination of non-living amorphous organic matter with heterotrophic and autotrophic microbes (Bowen 1979). The algal samples were observed under a dissecting microscope and found to contain predominantly filamentous algae from the Rhodophyta, Chlorophyta and Phaeophyta. After collection, the alimentary canal of each fish was removed to prevent contamination from ingested items, then all samples and fish were frozen and freeze dried to obtain dry weights.

Freeze dried samples were ground in a glass mortar and pestle, and lipids were extracted following the technique of Bligh \& Dyer (1959). The extracted lipids were filtered through combusted GF/C filter paper to remove particulate matter, concentrated by rotary evaporation and stored in $2 \mathrm{ml}$ vials. To estimate total lipid content, a $10 \mu \mathrm{l}$ aliquot was taken from the total lipid extract, the solvent evaporated on a hotplate set at $30^{\circ} \mathrm{C}$ and the remaining lipid weighed on a Perkin Elmer microbalance. Total lipid content was calculated from an average of 3 or 4 aliquots and expressed as a percentage of dry weight.

A portion of the remaining extract $(0.5 \mathrm{ml})$ was saponified and fatty acids methylated following the protocol of Nichols \& Espey (1991) to form fatty acid methyl esters. Fatty acid methyl esters were analysed on a Carba Erba ${ }^{\circledR}$ GC8000 GC-FID instrument (Milan, Italy) equipped with a DB-5MS column, $30 \mathrm{~m} \times 32 \mu \mathrm{m}$ in diameter ( $\mathrm{J}$ and $\mathrm{W}$ Scientific, MA, USA) using ChromCard $^{\mathrm{TM}}$ software. Samples were injected into a cold on-column injector and identified by comparing sample retention times to those of authentic standards (Sigma $^{\mathrm{TM}}$ ). Several samples were also analysed on a Hewlett Packard 6890 GC/MS system (Philadelphia, PA, USA) with the same capillary column. Mass spectra were used to confirm peak identifications and identify the structure of any unknown peaks. Complete procedural blanks and surrogate standards (23:0) were used to assess contamination and compound recoveries. Results from detritus and algae samples are a subset of results from Wilson et al. (2001).

The percentage of essential fatty acids and fatty acids that have previously been used as dietary biomarkers and were present in Salarias patzneri tissues, detritus and algae samples were compared using
MANOVA. Sample type (S. patzneri, detritus and algae) and seasons (summer and winter) were entered as fixed factors and data were arcsine or $\log _{10}(x+1)$ transformed before analysis to meet the assumptions of MANOVA (Zar 1999). Two-way ANOVAs in conjunction with Tukey's HSD (Honestly Significantly Different) were used as post hoc tests to assess any significant differences. Sequential Bonferonni corrections were applied to alpha levels to minimise the probability of type 1 error, whilst maintaining relatively high statistical power (Rice 1989). Fatty acid percentages or ratios that differed significantly between detritus and algae samples were presented graphically, as they had the potential to determine the source of dietary lipids for $S$. patzneri.

Results. The total lipid and fatty acid content of Salarias patzneri did not vary greatly between samples collected during the summer and winter (Table 1). The predominant fatty acids in fish collected during the summer were: 16:0, 22:6 $\omega 3,20: 5 \omega 3,22: 5 \omega 3,18: 1 \omega 9$

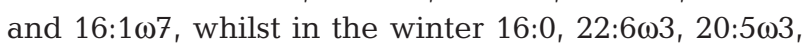
$16: 1 \omega 7,22: 5 \omega 3$ and $18: 1 \omega 9$ were the major fatty acids in descending order of abundance. Polyunsaturated fatty acids (PUFA) were the main fatty acids in fish samples collected during both seasons, accounting for approximately half of all the fatty acids. Detritus samples collected from $S$. patzneri territories during the summer and winter are dominated by the fatty acids 16:0 and 16:1 $1 \omega 7$, and together accounted for approximately $60 \%$ of all fatty acids in these samples. Algae samples collected from $S$. patzneri territories were dominated by 16:0,14:0 and 18:1 $\omega 9$, which when combined accounted for approximately $70 \%$ of all fatty acids in algae samples. Saturated fatty acids were the main type of fatty acids in both detritus and algae samples.

Essential fatty acids and fatty acids that have previously been used as indicators of diet, and were identified in Salarias patzneri tissues, detritus and algae samples, are listed in Table 2. The percentage/ratio of these fatty acids was significantly different in $S$. patzneri tissues, detritus and algae samples (Pillai's trace, $\mathrm{p}<0.001$ ), and between samples collected during the summer and winter (Pillai's trace, $\mathrm{p}=0.004$ ). However, there was no significant interaction between sample type and season. Post hoc ANOVAs indicated significant differences in the percentage/ratio of all essential fatty acids and dietary biomarkers between the different sample types (Table 2). Of these, only the $16: 1 \omega 7 / 16: 0$ ratio and percentages of $18: 2 \omega 6$ and 22:6 63 were significantly different in detritus and algal samples and therefore potentially useful in assessing the source of $S$. patzneri dietary lipids.

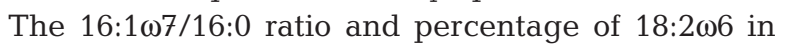
Salarias patzneri tissues and detritus samples were both 
Table 1. Fatty acids in Salarias patzneri tissues, detritus and filamentous algae samples collected from the epilithic algal matrix within $S$. patzneri territories. Values for individual fatty acids are the mean $\%$ of total fatty acids from 6 samples. Values in parentheses are standard errors. Trace indicates fatty acid was present at concentrations $<0.1 \%$

\begin{tabular}{|c|c|c|c|c|c|c|}
\hline & \multicolumn{2}{|c|}{ Salarias patzneri } & \multicolumn{2}{|c|}{ Detritus } & \multicolumn{2}{|c|}{ Algae } \\
\hline & Summer & Winter & Summer & Winter & Summer & Winter \\
\hline $\begin{array}{l}\text { Total lipids } \\
\text { (mg g }{ }^{-1} \text { dry wt) }\end{array}$ & $55.2(7.1)$ & $55.2(3.7)$ & $4.0(0.5)$ & $5.0(1.6)$ & $8.1(1.0)$ & $6.9(1.6)$ \\
\hline $\begin{array}{l}\text { Fatty acids } \\
\text { (\% total lipids) }\end{array}$ & $21.8(2.3)$ & $24.4(4.4)$ & $22.0(2.0)$ & $14.5(5.1)$ & $18.6(3.3)$ & $17.5(1.9)$ \\
\hline $13: 0$ & 0 & 0 & 0 & 0 & $0.7(0.2)$ & $0.2(0.1)$ \\
\hline $14: 0$ & $3.2(1.2)$ & $5.2(0.9)$ & $10.2(0.7)$ & $8.4(1.0)$ & $7.4(0.6)$ & $7.7(0.8)$ \\
\hline i15:0 & Trace & 0 & $0.7(0.1)$ & $0.4(0.1)$ & $0.7(0.2)$ & $0.4(0.1)$ \\
\hline a15:0 & Trace & Trace & $0.2(0.1)$ & $0.2(0.1)$ & Trace & $0.2(0.1)$ \\
\hline $15: 0$ & $0.5(0.1)$ & $0.7(0.1)$ & $1.3(0.2)$ & $1.1(0.2)$ & $3.4(0.7)$ & $1.5(0.3)$ \\
\hline $16: 1 \omega 7$ & $7.3(1.6)$ & $9.0(0.9)$ & $14.9(0.9)$ & $13.6(1.6)$ & $5.7(0.9)$ & $5.8(0.6)$ \\
\hline $16: 0$ & $23.5(1.7)$ & $24.7(0.5)$ & $44.3(0.9)$ & $48.4(1.4)$ & $53.5(4.4)$ & $56.0(0.8)$ \\
\hline $17: 0$ & $0.4(0.1)$ & $0.3(0.1)$ & $0.4(0.1)$ & $0.7(0.2)$ & $0.5(0.1)$ & $0.3(0.1)$ \\
\hline${ }_{18} \mathrm{PUFA}$ & $2.2(0.4)$ & $3.7(0.4)$ & $1.9(0.2)$ & $0.9(0.3)$ & $1.4(0.4)$ & $1.2(0.1)$ \\
\hline $18: 2 \omega 6$ & $2.5(0.1)$ & $3.1(0.3)$ & $2.5(0.2)$ & $3.5(0.7)$ & $4.0(0.7)$ & $4.1(0.3)$ \\
\hline $18: 1 \omega 9$ & $8.5(1.0)$ & $8.3(0.6)$ & $6.5(0.5)$ & $9.3(1.2)$ & $7.1(0.6)$ & $10.0(0.6)$ \\
\hline $18: 1 \omega 7$ & $2.3(0.1)$ & $1.9(0.2)$ & $4.3(0.4)$ & $4.9(0.7)$ & $6.2(0.6)$ & $6.0(0.5)$ \\
\hline $18: 0$ & $3.5(0.4)$ & $2.7(0.3)$ & $4.3(0.9)$ & $5.2(0.9)$ & $1.5(0.1)$ & $2.1(0.2)$ \\
\hline $20: 5 \omega 3$ & $10.9(1.3)$ & $9.3(0.7)$ & $2.6(0.3)$ & $1.4(0.3)$ & $3.0(1.0)$ & $2.1(0.3)$ \\
\hline $20: 4 \omega 6$ & $4.3(0.4)$ & $5.1(0.2)$ & $3.7(0.4)$ & $1.4(0.2)$ & $3.7(1.2)$ & $2.1(0.4)$ \\
\hline $22: 6 \omega 3$ & $20.3(2.4)$ & $16.7(1.3)$ & $1.7(0.2)$ & $0.2(0.1)$ & $0.6(0.6)$ & Trace \\
\hline $22: 5 \omega 3$ & $9.6(0.6)$ & $8.6(0.4)$ & 0 & 0 & $0.1(0.1)$ & 0 \\
\hline$\Sigma$ Saturate & $31.2(2.2)$ & $33.6(1.2)$ & $60.5(1.0)$ & $63.8(0.7)$ & $67.2(4.4)$ & $67.8(0.8)$ \\
\hline$\Sigma$ Mono & $18.0(0.7)$ & $19.3(0.7)$ & $25.8(0.5)$ & $27.9(0.5)$ & $19.0(0.5)$ & $21.8(0.4)$ \\
\hline$\Sigma$ Poly & $49.9(2.9)$ & $46.5(1.7)$ & $12.4(1.0)$ & $7.4(0.8)$ & $12.7(3.9)$ & $9.5(0.8)$ \\
\hline$\Sigma$ Branch & $0.2(0.1)$ & Trace & $0.9(0.2)$ & $0.7(0.2)$ & $0.8(0.2)$ & $0.6(0.1)$ \\
\hline $16: 1 / 16: 0$ & $0.29(0.06)$ & $0.36(0.03)$ & $0.34(0.02)$ & $0.28(0.03)$ & $0.12(0.03)$ & $0.10(0.01)$ \\
\hline$\omega 3 / \omega 6$ & $6.06(0.74)$ & $4.28(0.38)$ & $0.68(0.06)$ & $0.35(0.07)$ & $0.41(0.07)$ & $0.35(0.05)$ \\
\hline
\end{tabular}

very similar. However, high concentrations of 16:1 107 relative to 16:0 in detrital and $S$. patzneri tissues meant the $16: 1 \omega 7 / 16: 0$ ratio in these samples was significantly higher than algal samples, whilst the percentage of $18: 2 \omega 6$ in $S$. patzneri and detritus was significantly lower than in algal samples (Fig. 1). The percentage of

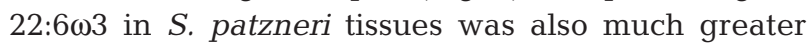
than in detritus samples, which was greater than in algal samples (Fig. 1). The percentage/ratio of the remaining fatty acids were similar between detritus and algae samples. The percentage of 20:5 $\omega 3,20: 4 \omega 6$ and the $\omega 3 / \omega 6$ ratio were, however, significantly greater in $S$. patzneri tissues than detritus and algae, and the sum of branched fatty acids was significantly lower in $S$. patzneri tissues than either detritus or algae. The $\omega 3 / \omega 6$ ratio and percentage of 22:6 $\omega 3$ in all sample types was also greater in samples collected during the summer.

Discussion. Significant differences in the 16:1 107 to 16:0 ratio in detritus and algal samples, and the relatively high percentage of these 2 fatty acids in all samples suggests that this ratio is a suitable biomarker for assessing if lipids in Salarias patzneri tissues are assimilated from detrital aggregates or filamentous algae.
The ratio of 16:1 107 to 16:0 has previously been used as an indicator of diet in krill (Virtue et al. 1993) and fish (St John \& Lund 1996), and high levels of 16:1 107 in body tissues used as dietary biomarkers in copepods

Table 2. Essential fatty acids and fatty acid ratios that have previously been related to diet and were identified in Salarias patzneri tissues, detritus and filamentous algae. Values are summary statistics from ANOVAs comparing fatty acid content/ratio in $S$. patzneri tissues, detritus and algae samples. *Significant difference after sequential Bonferroni adjustment to alpha levels

\begin{tabular}{|lrccc|}
\hline & \multicolumn{3}{c}{ Type } & \multicolumn{2}{c|}{ Season } \\
& $F_{2,30}$ & $\mathrm{p}$ & $F_{1,30}$ & $\mathrm{p}$ \\
\hline $18: 2 \omega 6$ & 5.1 & $0.012^{*}$ & 2.9 & 0.095 \\
$20: 5 \omega 3$ & 76.2 & $<0.001^{*}$ & 4.8 & 0.036 \\
$20: 4 \omega 6$ & 10.8 & $<0.001^{*}$ & 6.7 & 0.014 \\
$22: 6 \omega 3$ & 265.9 & $<0.001^{*}$ & 10.9 & $0.002^{*}$ \\
$\sum$ Branched $^{1,2}$ & 18.3 & $<0.001^{*}$ & 2.6 & 0.114 \\
$16: 1 / 16: 0^{3,4}$ & 24.8 & $<0.001^{*}$ & 0.003 & 0.960 \\
$\omega 3 / \omega 6^{5}$ & 344.2 & $<0.001^{*}$ & 12.0 & $0.002^{*}$ \\
References relating fatty acid to diet: ${ }^{1}$ Goedkoop et al. \\
$(1998),{ }^{2}$ Ederington et al. (1995), ${ }^{3}$ St John \& Lund (1996), \\
${ }^{4}$ Virtue et al. (1993), ${ }^{5}$ Dunstan et al. (1988) \\
\hline
\end{tabular}



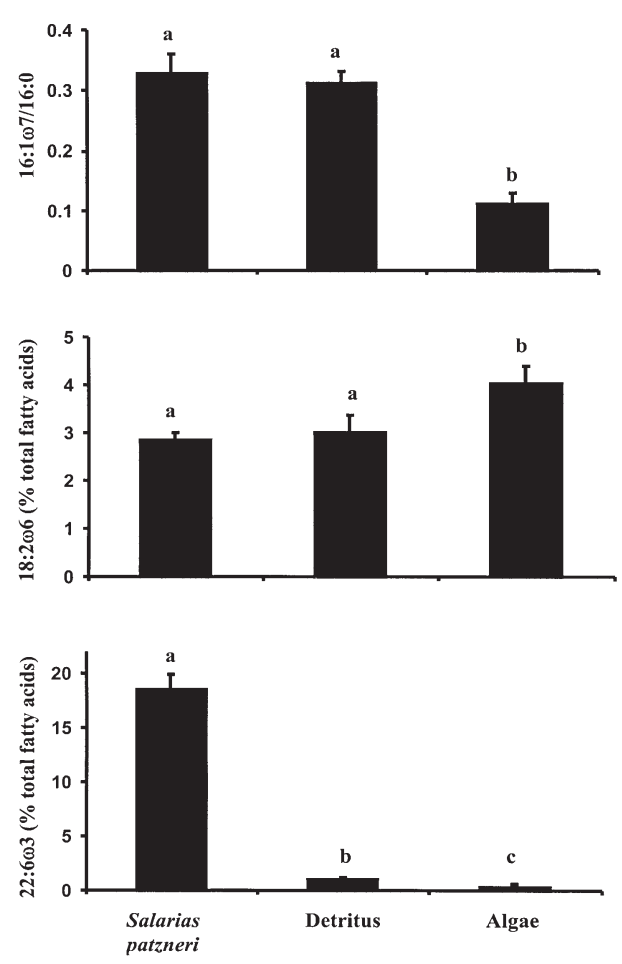

Fig. 1. Salarias patzneri, sources of lipids. Mean ratio or percentage of essential fatty acids and fatty acid biomarkers of potential use in discriminating between detritus and filamentous algae. Error bars are standard errors based on 12 samples. Letters above each column represent statistically similar groups, based on Tukey's HSD test

(Graeve et al. 1994) and midges (Goedkoop et al. 1998). The similarity of $16: 1 \omega 7$ to $16: 0$ ratios in $S$. patzneri tissues and detrital samples collected from their territories in the summer and winter strongly suggests that the dietary lipids in $S$. patzneri are primarily assimilated from detritus. Furthermore, the significantly lower ratio of $16: 1 \omega 7$ to $16: 0$ in algal samples suggests that the direct contribution of filamentous algae to lipids within $S$. patzneri tissues is limited.

An increase in the relative concentration of 16:1 107 in Salarias patzneri tissues and detritus compared to the filamentous algae could be due to the presence of diatoms in detritus samples. Diatoms are known to have high amounts of 16:1 17 (Volkman et al. 1989, Viso \& Marty 1993) and it is estimated that they account for up to $18 \%$ of the organic matter in sediments collected from $S$. patzneri territories (Wilson et al. in press). High concentrations of 16:1 $\omega 7$ in acanthurids that feed on the EAM have also been used to implicate diatoms as a dietary resource for these fish (Montgomery et al. 1999) and it has been shown that larval cod fed diatoms increase the ratio of 16:1 107 to 16:0 in their body tissues (St John \& Lund 1997). High concentrations of $16: 1 \omega 7$ in detritus and $S$. patzneri tissue relative to algae may, therefore, be an indication that diatoms are an important constituent of the $S$. patzneri diet. The ratio of $16: 1 \omega 7$ to $16: 0$ in $S$. patzneri tissues and detritus samples is, however, much lower than usually observed in diatom cultures (Volkman et al. 1989, Viso \& Marty 1996). The similarity of this ratio in $S$. patzneri tissues and detritus samples infers that it is both the detrital aggregates and diatoms within these aggregates that are assimilated, rather than just the diatoms.

Detritus collected from Salarias patzneri territories also contained fatty acids that are indicative of bacteria. Many bacteria have a high 16:1 17 content (Wilkinson 1988) and it is possible that they are a source of dietary lipids for $S$. patzneri. Bacteria are often characterised by branched fatty acids, which have previously been used as trophic biomarkers to indicate the movement of energy from bacteria through the food chain (Ederington et al. 1995, Goedkoop et al. 1998). It has been hypothesised that bacteria are a dietary resource for detritivorous reef fishes (Choat \& Clements 1998), a suggestion supported by the presence of branched fatty acids in $S$. patzneri tissues. This implies that lipids from bacteria are assimilated; however, these bacteria biomarkers accounted for less than $0.1 \%$ of the total fatty acids in $S$. patzneri tissues, much less than the 0.6 to $0.9 \%$ seen in detritus or 0.6 to $0.7 \%$ seen in filamentous algae samples. Furthermore, bacteria are unlikely to contain polyunsaturated fatty acids (Jantzen \& Bryn 1985), which accounted for approximately half of the total fatty acids in $S$. patzneri tissues. Consequently, it seems improbable that bacteria are a major source of dietary lipids for S. patzneri.

The other fatty acids that had significantly different percentages in detritus and algal samples were 18:2 $\omega 6$

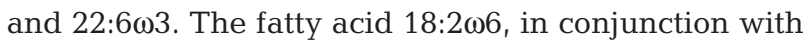
others, has previously been used as a dietary marker in crustaceans, fish, seals and river dolphins, and has been used to identify seagrass and angiosperm detritus in the diet (see Napolitano 1999). The 18:2 $\omega 6$ fatty acid is usually a minor component of diatoms (Volkman et al. 1989, Viso \& Marty 1993) and is often more prevalent in macroalgae (Johns et al. 1979, Vascovsky et al. 1996). A relatively low percentage of 18:2 $\omega 6$ in $S$. patzneri tissues and detritus samples, and a significantly higher percentage in algal samples, therefore supports the 16:1 $17 / 16: 0$ data which suggest that detrital aggregates are the major source of dietary lipids for this species.

The major PUFA in Salarias patzneri tissues was $22: 6 \omega 3$ and the percentage of this fatty acid in $S$. patzneri tissues was significantly greater than in detritus or algal samples. In many marine fish, it appears that 22:603 accumulates in tissues (Watanabe 1982), which would explain the relatively high concen- 
tration of this fatty acid in $S$. patzneri samples. This highly unsaturated fatty acid may also be produced by fish via the elongation and desaturation of other $\omega 3$ fatty acids (Kanazawa et al. 1979). Although it is possible that many marine fish lack the enzymes necessary for this conversion and rely solely on dietary sources of

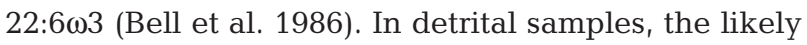

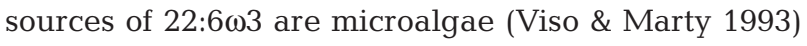
and copepods (Lee et al. 1971). However, the absence of copepod biomarkers 20:1 and 22:1 (Gatten et al. 1983, Clarke et al. 1987) in detritus or S. patzneri tissues suggests that $22: 6 \omega 3$ is primarily from microalgae.

In summary, this study suggests that detrital aggregates are a major source of dietary fatty acids for the blenny Salarias patzneri. Similarities in the ratio of $16: 1 \omega 7$ to $16: 0$ and the percentage of $18: 2 \omega 7$ in $S$. patzneri tissues and detrital samples indicate that fatty acids from detritus and microalgae, in particular diatoms, within detrital aggregates are assimilated by $S$. patzneri. These results, in conjunction with those from acanthurids, suggest that detritus and associated microalgae may be important dietary constituents for fish that feed on the EAM. Consequently, the ingestion and assimilation of detrital aggregates by fish may represent a major pathway for the transfer of energy on coral reefs.

Acknowledgements. This paper was improved by comments from D. R. Bellwood and R. Fisher. We gratefully acknowledge the support of staff at the Lizard Island Research Station, as well as K. Buckley, M. Marnane and R. Thomas for their help in the field, and B. Bowden and J. Cavanagh in the laboratory. P. Nichols kindly provided some advice and fatty acid standards. This is contribution number 1053 from the Australian Institute of Marine Science.

\section{LITERATURE CITED}

Bell MV, Henderson RJ, Sargent JR (1986) The role of polyunsaturated fatty acids in fish. Comp Biochem Physiol 83B:711-719

Bligh EG, Dyer WJ (1959) A rapid method of total lipid extraction and purification. Can J Biochem Physiol 37:911-917

Bowen SH (1979) A nutritional constraint in detritivory by fishes: the stunted population of Sarotherodon mossambicus in lake Sibaya, South Africa. Ecol Monogr 49:17-31

Choat JH (1991) The biology of herbivorous fishes on coral reefs. In: Sale PF (ed) The ecology of fishes on coral reefs. Academic Press, San Diego, p 120-155

Choat JH, Clements KD (1998) Vertebrate herbivores in marine and terrestrial environments: a nutritional ecology perspective. Annu Rev Ecol Syst 29:375-403

Clarke A, Holmes LJ, Hopkins CCE (1987) Lipid in an Artic food chain: Calanus, Bolinopsis, Beroe. Sarisia 72:41-48

Cowey CB, Sargent JR (1977) Lipid nutrition in fish. Comp Biochem Physiol 57B:269-273

Dunstan GA, Sinclair AJ, O'Dea K, Naughton JM (1988) The lipid content and fatty acid composition of various marine species from southern Australian coastal waters. Comp Biochem Physiol 91B:165-169
Ederington MC, McManus GB, Harvey RH (1995) Trophic transfer of fatty acids, sterols and a triterpenoid alcohol between bacteria, a ciliate and the copepod Acartia tonsa. Limnol Oceanogr 40:860-867

Fraser AJ, Sargent JR, Gamble JC, Seaton DD (1989) Formation and transfer of fatty acids in an enclosed marine food chain comprising phytoplankton, zooplankton and herring (Clupea harengus L.) larvae. Mar Chem 27:1-8

Gatten RR, Sargent JR, Gamble JC (1983) Diet-induced changes in fatty acid composition of herring larvae reared in enclosed ecosystems. J Mar Biol Assoc UK 63:575-584

Goedkoop W, Sonsten L, Markensten H, Ahlgren G (1998) Fatty acid biomarkers show dietary differences between dominant chironomid taxa in Lake Erken. Freshw Biol 40: 135-143

Graeve M, Kattner G, Hagen W (1994) Diet induced changes in the fatty acid composition of Arctic herbivorous copepods: experimental evidence of trophic markers. J Exp Mar Biol Ecol 182:97-110

Hatcher BG (1983) Grazing in coral reef ecosystems. In: Banes DJ (ed) Perspectives on coral reefs. Aust Inst Mar Sci, Townsville, p 164-179

Jantzen E, Bryn K (1985) Whole-cell and lipopolysaccharide fatty acids and sugars of gram-negative bacteria. In: Goodfellow M, Minnikin DE (eds) Chemical methods in bacterial systematics. Academic Press, Orlando, p 145-171

Johns RB, Nichols PD, Perry GJ (1979) Fatty acid composition of ten marine algae from Australian waters. Phytochemistry 18:799-802

Kanazawa A, Teshima S, Ono K (1979) Relationship between essential fatty acid requirements of aquatic animals and the capacity for bioconversion of linolenic acid to highly unsaturated fatty acids. Comp Biochem Physiol 63B: 295-298

Klungsoyr J, Tilseth S, Wilhelmsen S, Falk-Petersen S, Sargent JR (1989) Fatty acid composition as an indicator of food intake in cod larvae Gadus mohua from Lofoten, Northern Norway. Mar Biol 102:183-188

Lee RF, Nevenzel JC, Paffenhofer GA (1971) Importance of wax esters and other lipids in the marine food chain: phytoplankton and copepods. Mar Biol 9:99-108

Montgomery WL, Umino T, Nakagawa H, Vaughn I, Shibuno $\mathrm{T}$ (1999) Lipid storage and composition in tropical surgeonfishes (Teleostei: Acanthuridae). Mar Biol 133: 137-144

Napolitano GE (1999) Fatty acids as trophic and chemical markers in freshwater ecosystems. In: Arts MT, Wainman B (eds) Lipids in freshwater ecosystems. Springer-Verlag, New York, p 21-44

Nichols PD, Espey QI (1991) Characterisation of organic matter at the air-sea interface, in subsurface water and in bottom sediments near the Malabar sewage outfall in Sydney's coastal region. Aust J Mar Freshw Res 42:327-348

Purcell SW (1996) A direct method of assessing sediment load in epilithic algal communities. Coral Reefs 15:211-213

Rice WR (1989) Analysing tables of statistical tests. Evolution 43:223-225

Saito H, Yamashiro R, Alasalvar C, Konno T (1999) Influence of diet on fatty acids of three subtropical fish, subfamily Caesioninae (Caesio diagramma and C. stile) and Family Siganidae (Siganus canaliculatus). Lipids 34:1073-1082

St John MA, Lund T (1996) Lipid biomarkers: linking the utilization of frontal plankton biomass to enhanced condition of juvenile North Sea cod. Mar Ecol Prog Ser 131:75-85

Townsend KA, Tibbetts IR (2000) Biomass and distribution of herbivorous blennies in the southern Great Barrier Reef. J Fish Biol 56:774-791 
Vascovsky VE, Khotimchenko SV, Xia B, Hefang L (1996) Polar lipids and fatty acids of some marine macrophytes from the Yellow sea. Phytochemistry 42:1347-1356

Virtue P, Nichols PD, Nichol S, McMinn A, Sikes EL (1993) The lipid composition of Euphausia superba Dana in relation to the nutritional value of Phaeocystis pouchetii (Hariot) Lagerheim. Antart Sci 5:169-177

Viso AC, Marty JC (1993) Fatty acids from 28 marine microalgae. Phytochemistry 34(6):1521-1533

Volkman JK, Jeffrey SW, Nichols PD, Rogers GI, Garland CD (1989) Fatty acid and lipid composition of 10 species of microalgae used in mariculture. J Exp Mar Biol Ecol 128: 219-240

Watanabe $\mathrm{T}$ (1982) Lipid nutrition in fish. Comp Biochem Physiol 73B:3-15

Editorial responsibility: Kenneth Tenore (Contributing Editor), Solomons, Maryland, USA
Wilkinson SG (1988) Gram-negative bacteria. In: Ratledge C, Wilkinson SG (eds) Microbial lipids, Vol 1. Academic Press, London, p 525-566

Wilson SK (2000) Trophic status and feeding selectivity of blennies (Blenniidae: Salariini). Mar Biol 136:431-437

Wilson SK (in press) Multiscale habitat associations of detritivorous blennies (Blenniidae: Salariini). Coral Reefs

Wilson SK, Bellwood DR (1997) Cryptic dietary components of territorial damselfishes (Pomacentridae, Labroidei). Mar Ecol Prog Ser 153:299-310

Wilson SK, Burns K, Codi S (2001) Identifying components of a detritivorous reef fish diet using lipid biomarkers. Org Geochem 32(10):1257-1269

Zar JH (1999) Biostatistical analysis, 4th edn. Prentice-Hall, New York

Submitted: January 30, 2001; Accepted: August 13, 2001

Proofs received from author(s): October 5, 2001 